\title{
PROJECTED INCIDENCE OF OVERWEIGHT AND OBESITY AND RELATED DISEASE INCIDENCE ACROSS POLAND
}

\author{
Laura Webber ${ }^{1}$, Ewa Halicka ${ }^{2}$, Tim Marsh ${ }^{1}$, Ketevan Rtveladze ${ }^{1}$, Klim McPherson ${ }^{3}$, Martin Brown ${ }^{1}$ \\ ${ }^{1}$ UK Health Forum, London, United Kingdom \\ ${ }^{2}$ Faculty of Human Nutrition and Consumer Sciences, Warsaw University of Life Sciences, Warsaw, Poland \\ ${ }^{3} \mathrm{New}$ College, University of Oxford, Oxford, United Kingdom
}

\begin{abstract}
SUMMARY
The first objective is to project obesity trends to 2030 based on the current data from Poland. The second objective is to test the effect of a $1 \%$ or $5 \%$ decrease in population BMI upon future incidence and prevalence of related non-communicable diseases. A two-stage modelling design projecting overweight and obesity trends and related diseases in a microsimulation model was developed. Epidemiological data for entry into a microsimulation model were gathered from Poland. This study used population level data from Poland creating a virtual population within a microsimulation model. Obesity and overweight in Poland was found to increase to very high levels in men while trends remained unchanged in women. In a country that currently has about 38 million inhabitants, it is anticipated that by 2030, there might be more than 9 million new cancer cases; 10 million CHD and stroke cases, and 7 million new cases of type 2 diabetes. These findings have policy implications highlighting the need for action to curb trends and to reduce increases in the rates of diet-related non-communicable disease.
\end{abstract}

Key words: trend, obesity, non-communicable disease, coronary heart disease, modelling

Address for correspondence: L. Webber, The UK Health Forum, Fleetbank House, 2-6 Salisbury House, London, EC4Y 8JX, United Kingdom. E-mail: laura.webber@heartforum.org.uk

\section{INTRODUCTION}

During the post-war period and communist rule in Poland (1945-1989) the market offer of processed foods was modest. Food consumption was characterised by a high level of self-supply and seasonality. In the 1980s due to political and economic crises food rationing was introduced. In the posttransition period dynamic food industry development and international trade growth contributed to significant changes in the dietary behaviour of Polish consumers. For example, total annual fat consumption per capita increased in the years 1990-2008 by 30\% reaching almost $31 \mathrm{~kg}$, despite the drop in butter consumption from $7.8 \mathrm{~kg}$ to $4.3 \mathrm{~kg}$. Movement to a free market economy resulted in greater availability of cheap, highly calorific food and as a result, an obesity epidemic across Eastern Europe, with rates sometimes higher than countries of Western or Northern Europe $(1,2)$. Because of the role obesity plays in the development of non-communicable diseases (NCDs) such as coronary heart disease and type 2 diabetes (3-7), increasing obesity rates is an important public health problem rising costs of public health care.

Data on overweight and obesity ratios during and after the transformation period in Poland are scarce and often give a mixed picture of the situation. For example POL-MONIKA studies in the population of Warsaw showed no changes in body mass index (BMI) among women and a growing tendency in men in the period from 1988-2003. Local epidemiological studies in the years 1993 and 2003 demonstrated that the percentage of obese women increased in ten years in the Silesian region from $8.9 \%$ to $15 \%$ while the prevalence of obesity among men did not change significantly (8). According to results published in 2004, prevalence of obesity among 19-year-old men increased from $0.8 \%$ in 1986 to $1.6 \%$ in 1995 and 2.5\% in 2001 (9). In the last decade two nationwide representative population studies on obesity based on anthropometric mea-surements were carried out and indicated that excess body weight started to be a growing health problem in Poland.

In 2000-2001, the "Food consumption and anthropometric survey project”, financially supported by the Food and Agriculture Organization (FAO) and conducted by the Food and Nutrition Institute among 2,825 adults, showed that $41.7 \%$ of men and $28.7 \%$ of women in Poland were overweight while $15.7 \%$ of men and $19.9 \%$ of women were obese (10). The Multicenter Polish Health Status Population Survey conducted in the years 2003-2005 and coordinated by the Cardiology Institute in Warsaw pointed to higher prevalence of obesity. Approximately $40 \%$ of the measured men and $28 \%$ of women were overweight and $21.2 \%$ of men and $22.4 \%$ of women were found to be obese (11). BMI calculations were made with the use of data from 13,408 individuals aged 20-74. The most recent available calculations based on self-measurement collected by the Central Statistical Office of Poland in 2009 (extracted from the European Health Interview Survey database (EHIS) show that obesity level among $15+$ year-old men oscillates around $16.5 \%$ and among women around $15.2 \%$. Prevalence of overweight is estimated at $44.8 \%$ in men and $29.4 \%$ in women (12). 
Such high overweight and obesity rates are a key public health problem because of the increased risk of developing chronic, noncommunicable diseases such as type 2 diabetes, cardiovascular disease (CVD), and obesity-related cancers (3-7). These trends point to a future high cost burden on the health care system and/ or a high mortality rate from fatal NCDs such as cardiovascular disease (CVD) or cancer. One Polish study diagnosed 7\% of individuals in a representative study population with diabetes and a further 9.5\% with impaired fasting glucose (IFG) (13). According to health experts the decline in mortality due to cardiovascular disease from 1991-1994 can be linked to policy measures which reduced subsidies on dairy and other animal fats resulting in price changes and increases in polyunsaturated and decreases in saturated fat consumption (14). Further research conducted by Zatoński and his coworkers in the "Closing the health gap in the EU” project showed that cardiovascular mortality ratio kept decreasing among both men and women in Poland (15). However, introduction of new and effective policy measures is needed to sustain this trend and to challenge the risk of other diseases, such as obesity.

Projection of obesity trends and related NCDs is important for the planning of future health policies and expenditures. This study uses microsimulation modelling to project BMI trends and related diseases (coronary heart disease, stroke, type 2 diabetes, and obesity-related cancers - breast, colorectal, liver, kidney, endometrial, pancreas, and oesophagus) to 2030. It tests two hypothetical scenarios: the effect of a $1 \%$ and $5 \%$ decrease in $\mathrm{BMI}$ upon disease prevalence and incidence rates.

\section{MATERIALS AND METHODS}

Body mass index (BMI) data stratified by age and sex and categorised into standard groupings for normal weight (18.5-24.99 $\left.\mathrm{kg} / \mathrm{m}^{2}\right)$, overweight $\left(25-29.99 \mathrm{~kg} / \mathrm{m}^{2}\right)$ and obesity $\left(\geq 30 \mathrm{~kg} / \mathrm{m}^{2}\right)$ were collected from a literature search using Pubmed and Google scholar. The World Health Organization (WHO) BMI database, Eurostat database and personal communication were also used to gather additional data. A second literature review was carried out to locate incidence, mortality and survival data for coronary heart disease, stroke, obesity-related cancers (breast, colorectal, liver, kidney, endometrial, pancreas, oesophagus) and incidence data for type 2 diabetes.

Subnational data from 1992 were available in the WHO BMI database gained from the WHO CINDI project. Three nationally representative datasets from years 1996, 2004 and 2009 with BMI data from self-reported height and weight were supplied by the Central Statistical Office of Poland (CSO). The data for 1996 and 2004 were the results of the Polish Health Interview Survey and for 2009 of the European Health Interview Survey (EHIS). Samples for all household surveys were carried out by CSO and selected with the application of a two-stage sampling scheme. A sampling frame used to select this type of sample was based on the TERYT system, i.e. the Domestic Territorial Division Register. Dwellings (together with the addresses) were the second-stage sampling units. All households in selected dwellings were surveyed. In each household all individuals were interviewed (in the case of BMI - people aged 15 or more years).

Table 1. BMI references of data included in the model (Poland)

\begin{tabular}{|l|c|c|c|c|c|c|}
\hline Data source & Data years & $\begin{array}{c}\text { Sample size, } \\
\text { males }\end{array}$ & $\begin{array}{c}\text { Sample size, } \\
\text { females }\end{array}$ & Age groups & $\begin{array}{c}\text { Measured/ } \\
\text { self-reported } \\
\text { data }\end{array}$ & $\begin{array}{c}\text { Nationall } \\
\text { subnational } \\
\text { data }\end{array}$ \\
\hline WHO; CINDI, 2003 & 1992 & 792 & 904 & $25-64$ & measured & subnational \\
\hline $\begin{array}{l}\text { Eurostat database: National Health Interview } \\
\text { Survey for Poland }\end{array}$ & 1996 & 3,137 & 9,411 & $15-100$ & self-reported & national \\
\hline $\begin{array}{l}\text { Szponar et al. Household food consumption and } \\
\text { anthropometric survey, 2003 (10) }\end{array}$ & 2001 & \multicolumn{2}{|c|}{1,949} & $19-100$ & both & national \\
\hline Statistical Office Poland, personal communication & 2004 & 19,335 & 19,446 & $15-70$ & self-reported & national \\
\hline Statistical Office Poland, personal communication & 2009 & 11,932 & 14,673 & $15-70$ & self-reported & national \\
\hline
\end{tabular}

Table 2. Disease references of data included in the model (Poland)

\begin{tabular}{|l|l|l|l|}
\hline Disease & Incidence & Mortality & Survival \\
\hline Diabetes & http://www.healthmetricsandevaluation.org/search-gbd-data & non-fatal & non-fatal \\
\hline CHD & UK proxy, Heartstats & WHO 2008 & Heartstats 28 CF \\
\hline Stroke & Wawrzyńczyk et al., 2011 & WHO 2008 & EU Chronic disease report, 2007 \\
\hline Cancers & & & \\
\hline Breast & Globocan 2008 & Globocan 2008 & Gondos et al., 2008 \\
\hline Colorectal & Globocan 2008 & Globocan 2008 & Gondos et al., 2008 \\
\hline Endometrial & Globocan 2008 & Globocan 2008 & Gondos et al., 2008 \\
\hline Kidney & Globocan 2008 & Globocan 2008 & Gondos et al., 2008 \\
\hline Liver & Globocan 2008 & Globocan 2008 & Gondos et al., 2008 \\
\hline Oesophagus & Globocan 2008 & Globocan 2008 & Gondos et al., 2008 \\
\hline Pancreatic & Globocan 2008 & Globocan 2008 & Gondos et al., 2008 \\
\hline
\end{tabular}


A fifth national dataset from 2001 was taken from the WHO BMI database (16). References for these data can be found in Table 1. The disease data in the model are included in Table 2.

\section{Statistical Analysis}

The Foresight working group developed a two-part modelling process that was used in the current analyses (17). The first part applies a multivariate, categorical regression analysis to cross-sectional BMI data by age and sex from Poland. Age and calendar years are included as covariates and the predicted proportions of population in each BMI category were constrained to sum up to $100 \%$. The $95 \%$ confidence intervals were produced from Bayesian posterior distribution of the regression parameters.

The second part of the modelling process applies a microsimulation programme to enable longitudinal projections. This creates a virtual population of Polish individuals based on projected BMI distributions from 2010-2030 and current population statistics (births, deaths, age, and sex distributions). BMI values were randomly assigned as a function of age, sex and calendar year. Further details of the statistical analyses can be found in the study by Wang et al. (18).

The results were determined by three scenarios: scenario 0 ) trends continue as predicted; scenario 1) trends decrease by $1 \%$ relative to scenario 0 ; scenario 2 ) trends decrease by $5 \%$ relative to scenario 0 . This method includes data on the population structure of Poland illustrated in Fig. 1.

\section{RESULTS}

Fig. 2 presents the current and projected prevalence of overweight and obesity in men and women to 2030. Male BMI shows a sharp and steady increase from 2010 to 2030. Women show a slight increase over time. The overall number of men and women (15 years + ) in the Polish population in 2009 was 32,617,000 according to CSO Based on EHIS results altogether, 4,270,000 people, of which 2,246,000 women and 2,024,000 men were estimated as being obese (BMI $\left.\geq 30 \mathrm{~kg} / \mathrm{m}^{2}\right)(12)$. Based on our projections more than 13 million adults $-18 \%$ of men and $23 \%$ of women - will be obese $\left(\geq 30 \mathrm{~kg} / \mathrm{m}^{2}\right)$ by 2030 . If trends do not slow down, by 2030, 79\% of men and 50\% of women in Poland will be either overweight or obese (BMI $\geq 25 \mathrm{~kg} / \mathrm{m}^{2}$ ).

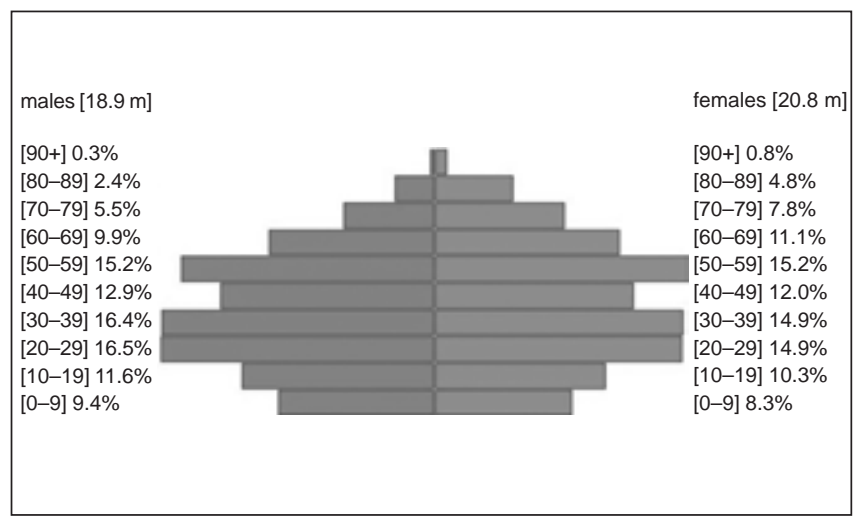

Fig. 1. Population pyramid Poland.

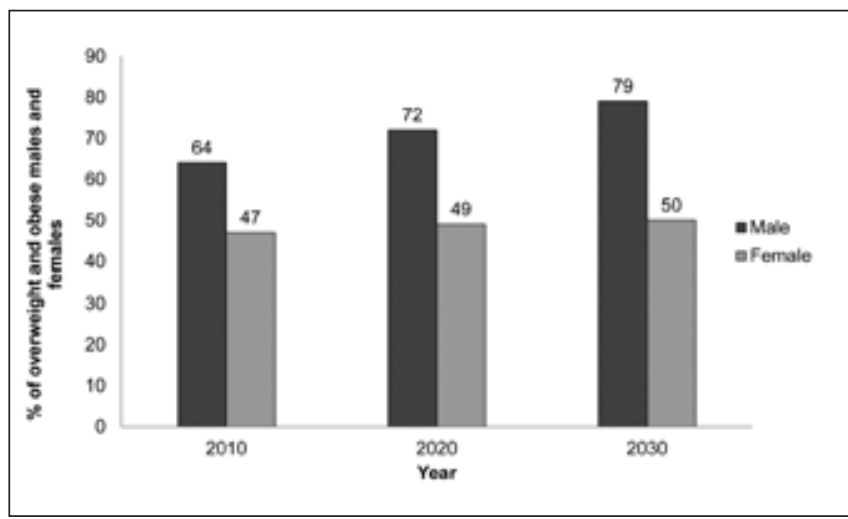

Fig. 2. Overweight and obesity projections to 2030 in males and females.

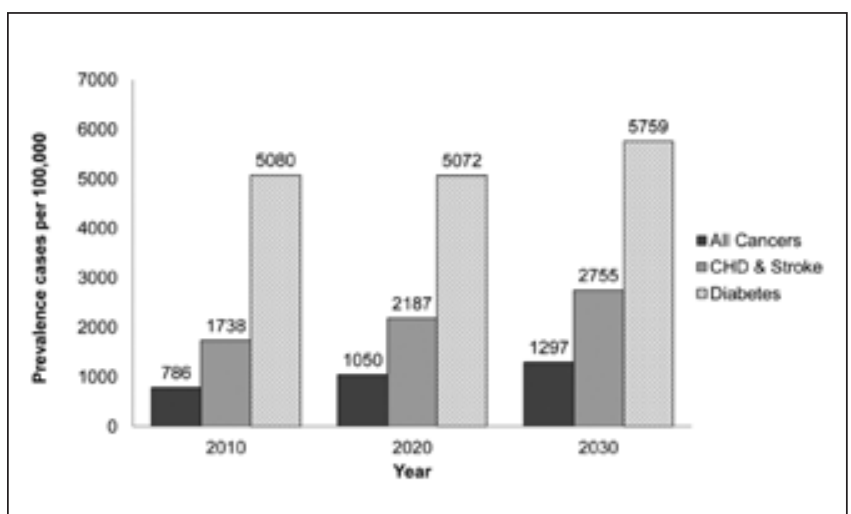

Fig. 3. Projected prevalence of each disease from 2010 to 2030 per 100,000 of the population in Poland.

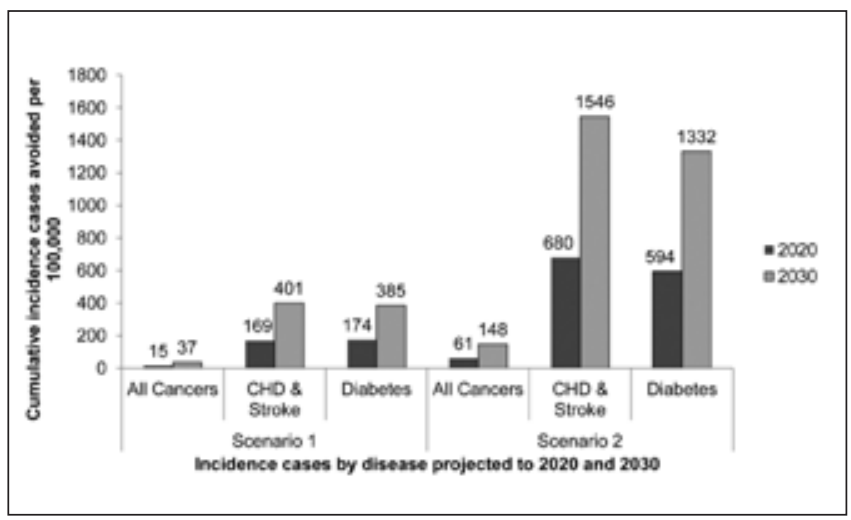

Fig. 4. Cumulative incidence cases avoided per 100,000.

Fig. 3 presents the projected prevalence of each disease from 2010 to 2030 per 100,000 of the population. The burden of disease increases over time, e.g. rates of type 2 diabetes are predicted to increase from 5,080 prevalence cases in 2010 to 5,759 cases per 100,000 of the population. Fig. 4 presents the projected cumulative incidence of cases avoided in 2020 and 2030 per 100,000 of the population in 2010 given a $1 \%$ (scenario 1) or $5 \%$ (scenario 2) decrease in population BMI. It is clear that a $5 \%$ reduction in population BMI would have a particularly significant impact upon the incidence of CHD, stroke and type 2 diabetes.

Table 3 presents the cumulative incidence rates and prevalence cases avoided by scenario. Cumulatively, it is predicted that there may be more than 1 million new cancer cases, almost 8 million 
Table 3. Cumulative incidence cases from year 2010 (per 100,000 of population in 2010)

\begin{tabular}{|c|c|c|c|}
\hline Year & Cancers & CHD \& Stroke & Diabetes \\
\hline \multicolumn{4}{|c|}{ Scenario 0} \\
\hline 2010 & $132(+3)$ & $987(+9)$ & $203(+4)$ \\
\hline 2020 & $1,674(+12)$ & $10,546(+31)$ & $2,426(+15)$ \\
\hline 2030 & $3,857(+21)$ & $23,564(+51)$ & $5,396(+25)$ \\
\hline \multicolumn{4}{|c|}{ Scenario 1} \\
\hline 2010 & $133(+3)$ & $988(+9)$ & $203(+4)$ \\
\hline 2020 & $1,659(+12)$ & $10,377(+31)$ & $2,252(+14)$ \\
\hline 2030 & $3,820(+21)$ & $23,163(+51)$ & $5,011(+24)$ \\
\hline \multicolumn{4}{|c|}{ Scenario 2} \\
\hline 2010 & $132(+3)$ & $988(+9)$ & $200(+4)$ \\
\hline 2020 & $1,613(+12)$ & $9,866(+30)$ & $1,832(+13)$ \\
\hline 2030 & $3,709(+20)$ & $22,018(+49)$ & $4,064(+21)$ \\
\hline
\end{tabular}

Table 4. Probability of BMI - Group by age-group and gender projected to 2030

\begin{tabular}{|c|c|c|c|c|c|c|c|c|c|}
\hline & $\begin{array}{l}2010 \\
(<25)\end{array}$ & $\begin{array}{c}2010 \\
(25-30)\end{array}$ & $\begin{array}{l}2010 \\
(>30)\end{array}$ & $\begin{array}{l}2020 \\
(<25)\end{array}$ & $\begin{array}{c}2020 \\
(25-30)\end{array}$ & $\begin{array}{l}2020 \\
(>30)\end{array}$ & $\begin{array}{l}2030 \\
(<25)\end{array}$ & $\begin{array}{c}2030 \\
(25-30)\end{array}$ & $\begin{array}{l}2030 \\
(>30)\end{array}$ \\
\hline $0-4, M$ & 0.99 & 0.01 & 0.01 & 0.99 & 0.01 & 0.01 & 0.99 & 0.01 & 0.01 \\
\hline $0-4, F$ & 0.99 & 0.01 & 0.01 & 0.99 & 0.01 & 0.01 & 0.99 & 0.01 & 0.01 \\
\hline $5-9, M$ & 0.97 & 0.03 & 0.00 & 0.97 & 0.03 & 0.00 & 0.97 & 0.03 & 0.00 \\
\hline $5-9, F$ & 0.97 & 0.03 & 0.00 & 0.97 & 0.03 & 0.00 & 0.97 & 0.03 & 0.00 \\
\hline $10-14, \mathrm{M}$ & 0.87 & 0.11 & 0.02 & 0.87 & 0.11 & 0.02 & 0.87 & 0.11 & 0.02 \\
\hline $10-14, F$ & 0.85 & 0.12 & 0.03 & 0.85 & 0.12 & 0.03 & 0.85 & 0.12 & 0.03 \\
\hline $15-19, \mathrm{M}$ & 0.75 & 0.18 & 0.06 & 0.75 & 0.18 & 0.06 & 0.75 & 0.18 & 0.06 \\
\hline $15-19, \mathrm{~F}$ & 0.71 & 0.19 & 0.10 & 0.71 & 0.19 & 0.10 & 0.71 & 0.19 & 0.10 \\
\hline $20-24, \mathrm{M}$ & 0.66 & 0.28 & 0.06 & 0.54 & 0.36 & 0.10 & 0.40 & 0.43 & 0.17 \\
\hline $20-24, F$ & 0.87 & 0.10 & 0.03 & 0.83 & 0.11 & 0.06 & 0.76 & 0.12 & 0.11 \\
\hline $25-29, \mathrm{M}$ & 0.66 & 0.28 & 0.06 & 0.54 & 0.36 & 0.10 & 0.41 & 0.42 & 0.17 \\
\hline $25-29, F$ & 0.87 & 0.1 & 0.03 & 0.83 & 0.11 & 0.05 & 0.78 & 0.13 & 0.09 \\
\hline 30-34, M & 0.32 & 0.50 & 0.17 & 0.26 & 0.52 & 0.22 & 0.19 & 0.53 & 0.27 \\
\hline $30-34, F$ & 0.63 & 0.27 & 0.10 & 0.65 & 0.26 & 0.09 & 0.66 & 0.26 & 0.08 \\
\hline $35-39, \mathrm{M}$ & 0.32 & 0.50 & 0.17 & 0.26 & 0.52 & 0.22 & 0.19 & 0.53 & 0.27 \\
\hline $35-39, F$ & 0.63 & 0.27 & 0.10 & 0.65 & 0.26 & 0.09 & 0.66 & 0.26 & 0.08 \\
\hline $40-44, \mathrm{M}$ & 0.33 & 0.50 & 0.18 & 0.26 & 0.52 & 0.23 & 0.20 & 0.53 & 0.28 \\
\hline $40-44, \mathrm{~F}$ & 0.63 & 0.27 & 0.10 & 0.64 & 0.26 & 0.09 & 0.66 & 0.26 & 0.09 \\
\hline $45-49, \mathrm{M}$ & 0.33 & 0.50 & 0.18 & 0.26 & 0.52 & 0.23 & 0.20 & 0.53 & 0.28 \\
\hline $45-49, \mathrm{~F}$ & 0.63 & 0.27 & 0.10 & 0.64 & 0.26 & 0.09 & 0.66 & 0.26 & 0.09 \\
\hline $50-54, \mathrm{M}$ & 0.25 & 0.5 & 0.25 & 0.18 & 0.53 & 0.30 & 0.12 & 0.54 & 0.34 \\
\hline $50-54, F$ & 0.35 & 0.39 & 0.26 & 0.35 & 0.39 & 0.27 & 0.34 & 0.38 & 0.28 \\
\hline $55-59, \mathrm{M}$ & 0.25 & 0.50 & 0.25 & 0.18 & 0.53 & 0.30 & 0.12 & 0.54 & 0.34 \\
\hline $55-59, \mathrm{~F}$ & 0.35 & 0.39 & 0.26 & 0.35 & 0.39 & 0.27 & 0.34 & 0.38 & 0.28 \\
\hline $60-64, \mathrm{M}$ & 0.25 & 0.5 & 0.25 & 0.18 & 0.52 & 0.30 & 0.12 & 0.53 & 0.35 \\
\hline $60-64, F$ & 0.35 & 0.39 & 0.26 & 0.35 & 0.39 & 0.27 & 0.35 & 0.38 & 0.27 \\
\hline $65-69, \mathrm{M}$ & 0.25 & 0.50 & 0.25 & 0.18 & 0.52 & 0.30 & 0.12 & 0.53 & 0.35 \\
\hline $65-69, F$ & 0.35 & 0.39 & 0.26 & 0.35 & 0.39 & 0.27 & 0.35 & 0.38 & 0.27 \\
\hline $70-74, \mathrm{M}$ & 0.30 & 0.51 & 0.19 & 0.19 & 0.55 & 0.27 & 0.11 & 0.55 & 0.34 \\
\hline $70-74, F$ & 0.33 & 0.45 & 0.23 & 0.23 & 0.51 & 0.26 & 0.15 & 0.56 & 0.30 \\
\hline $75+, M$ & 0.30 & 0.51 & 0.19 & 0.19 & 0.55 & 0.27 & 0.11 & 0.55 & 0.34 \\
\hline $75+, F$ & 0.33 & 0.45 & 0.23 & 0.23 & 0.51 & 0.26 & 0.15 & 0.56 & 0.30 \\
\hline
\end{tabular}


CHD and stroke cases and nearly 2 million new cases of type 2 diabetes by 2030 due to increasing rates of overweight and obesity.

Table 4 presents the probability of BMI-Group by age-group and gender projected to 2030. Overweight and obesity is projected to increase sharply in men, but is mostly level in women over time, with a slight increase or decrease depending upon age group.

\section{DISCUSSION}

This study used microsimulation modelling to project BMI trends and studied diseases in Poland until 2030 and tested the effect of two hypothetical scenarios that reduced BMI by $1 \%$ and $5 \%$ upon disease incidence and prevalence rates. It is alarming that rates of overweight and obesity are predicted to rise to such high rates, especially in men. The hypothetical scenarios usefully demonstrate how important decreases in BMI can be. With a well thought out and effective health policy aimed at life-style change of consumers, Poland could considerably reduce the burden of ill-health brought about by obesity.

It is clear that in order to prevent obesity among adults, policy measures relating to healthy eating in schools are necessary. According to a report published by the Mother and Child Institute in Warsaw, $10.2 \%$ of $14-15$ year-old boys and $11.9 \%$ of $14-15$ year-old girls had potentially harmful excessive body weight in 2005 (based on child growth standards) (19). Some studies (many of them published only in Polish) explore the specificities of activities carried out in Polish schools linked to promotion of healthy diets. However, the participation of schools in obesity prevention in Poland is not satisfactory.

In April 2010, a "School Environment and Health" questionnaire developed in the frame of the 2009/2010 Health Behaviour in School-aged Children (HBSC) study was posted to 700 randomly selected primary, secondary and cluster schools in Poland. Overall 520 questionnaires were returned, in almost $75 \%$ of cases answered by head teachers. The majority of schools admitted having informal nutrition policies, only $25.7 \%$ had a written policy on the consumption of healthy foods, $10 \%$ on limiting sweets, chips, soft drinks, and other junk food, and only $7 \%$ had a written policy stating that fruits and vegetables should be offered at school events. The article concluded that "there is a burning need to develop a coherent nutritional policy in Poland at the regional, local and school level” (20).

Since Poland's integration with the European Union in 2004 and the introduction of the EU funded Fruit Scheme (within the Common Agricultural Policy) the number of primary-school pupils participating in the scheme reached almost 800,000 (21). In 2006, the Chief Sanitary Inspectorate (the institute responsible for public health in Poland) together with the Polish Federation of Food Industry addressed the growing problem of overweight and obesity among school children. This partnership led to the creation of the "Keep Fit" educational programme implemented in $28 \%$ of primary schools and in $72 \%$ of lower-secondary schools (21). The programme uses the "project" technique and consists of an educational pack for teachers, students and parents. Additionally, more and more local authorities in big cities (Warsaw, Gdańsk) are becoming involved in promoting of healthy lifestyle. Based on a qualitative study conducted in 2004-2005, which explored the views of stakeholders towards various obesity policies such as health education, technological solutions, modifying the environment to improve physical activity, there is no single option that would be sufficient to address the problem of obesity (22).

Despite activities carried out by research and academic institutions including publishing long- and short-term plans and recommendations for the government - no national programme aimed at improving the lifestyle of Poland's population was implemented before 2006. Only in response to the WHO initiative expressed in the Global Strategy on Diet, Physical Activity and Health (Geneva, 2004) POL-HEALTH - a National Programme for the Prevention of Overweight, Obesity and Non-Communicable Diseases through Diet and Improved Physical Activity was approved by the Minister of Health. POL-HEALTH is compliant with the European Charter on Counteracting Obesity signed on 16 November 2006 by 48 countries of the WHO European Region in Istanbul and also with the state health policy (23). At its initial stage the estimated cost of the programme implementation was estimated at $85 \mathrm{mln}$ PLN. The POL-HEALTH budget for 2007-2011 was planned at 12,207,000 PLN. However, according to the Minister of Health due to cost modification and cuts only 3.5 mln PLN (800,000 euro) was spent during the first 7 years of POL-HEALTH.

In November 2007, the Polish Diet, Physical Activity and Health Council was established in Poland by the Minister of Health. In January 2008, the first meeting of the council members took place. The 25 members represent public institutions (such as the Ministry of Health, Ministry of Education and Ministry of Sports), academic, health as well as nutrition research centers, the Polish food and drink industry, consumer organisations, health related NGOs and media.

The Council is based on a partnership approach inspired by the activities of the European Diet, Physical Activity and Health Platform, created in 2005 by the Directorate-General for Health and Consumers (DG SANCO). It is an advisory body of the Polish Ministry of Health in the field of food, nutrition and physical activity. In 2011, the Council members prepared a new healthy life-style education tool (The Health Plate) and the launch of a new website to promote the activities of the Ministry of Health in the field of nutrition was expected in 2012. A multi-stakeholder, intersectoral and partnership-based approach, led and supervised by governmental administration seems to be the best solution to handle the obesity epidemic.

Due to financial and structural (organisational) constraints, despite the development of long-term programmes (enhanced by EC and WHO activites), no major government-supervised nation-wide obesity-fighting intervention has yet been carried out in Poland (as in many other countries). Therefore, its effectiveness cannot be studied or proven. Two so-called Operational Objectives (out of 6 concerning the area of health promotion) i.e. "Improving nutritional habits of the population and the health quality of food: reducing prevalence of obesity" and "Increasing physical activity of the population" are included in the current National Health Programme (2007-2015). Its outcome has to be evaluated in the future.

The results of the microsimulation modelling look at the current situation based on available data. It is an estimation that may "open the eyes" of policy makers, stakeholders (food industry, NGOs) and consumers. However, the model is dependent upon 
the quality of the data input into it and unfortunately a full set of disease data was not available for Poland. We used proxy country data for CHD (UK proxy) incidence and survival (UK proxy). In addition, data were either subnational or self-reported and national meaning predictions should be considered with this limitation in mind. Self-reported height and weight data are notoriously underreported (24). Furthermore, women are more likely to underreport weight than men as well as overweight and obese than normal weight individuals (25). This is interesting since our results show that overweight and obesity increases sharply in men, but is mostly level in women over time, with a slight increase or decrease depending upon age group (Table 4). Errors in self-report might reflect this discrepancy suggesting that rates are higher in the total population. Measured, nationally represented data sets are needed.

As well as adult obesity, childhood obesity is a major public health concern since weight tracks over time. Recent data has shown an alarming increase in obesity in children in Poland and other countries (26-28). Poland has a fairly young population and also low birth rate (1.29), thus the potential to curb rates in the young so that rising rates of chronic diseases in middle-age are halted. Due to lack of representative data we were not able to include data on children into this study (29). For this reason we assumed childhood obesity trends to be stable and the level they were set in the microsimulation was conservative. The effect of this is that the recent increase in childhood obesity in Poland was missed and as weight tracks, trends in adulthood are underestimated. In addition, the programme assumes that people do not reverse their BMI categories. However, this reflects reality where BMI group rarely changes as weight loss is hard to maintain.

These findings present an important story for policy makers and public health and nutrition experts in Poland. If rates fail to halt then the proportion of chronic non-communicable diseases will escalate placing a burden on the public health system (and economy as a whole), long-term suffering (lowering of quality of life) of many millions of men and women and premature death from preventable diseases (30). It is important to monitor the situation as well as intensify the actions on local and national level including educating young consumers on healthy food choices not to gain weight.

\section{Acknowledgement}

We would like to thank GlaxoSmithKline for providing a non-discretionary education grant to fund this project.

\section{Conflict of Interests}

None declared

\section{REFERENCES}

1. Berghöfer A, Pischon T, Reinhold T, Apovian CM, Sharma AM, Willich SN. Obesity prevalence from a European perspective: a systematic review. BMC Public Health. 2008 Jun 5;8:200.

2. Tekkel M, Veideman T, Rahu M. Changes over fourteen years in adult obesity in Estonia: socioeconomic status and use of outpatient health services. Cent Eur J Public Health. 2010 Dec;18(4):186-91.

3. Hujová Z, Alberty R, Ahlers I, Ahlersová E, Paulíková E, Desatníková J, et al. Cardiovascular risk predictors in Central Slovakian Roma children and adolescents: regional differences. Cent Eur J Public Health. 2010 Sep;18(3):139-44.

4. Gikas A, Sotiropoulos A, Panagiotakos D, Pappas S. Prevalence of self-reported myocardial infarction in a Greek sample: findings from a population-based study in an urban area (medical express 2002). Cent Eur J Public Health. 2004 Dec;12(4):207-10

5. Vangelova K, Deyanov C. Dyslipoproteinemias in industrial workers: relationship with hypertension and overweight. Cent Eur J Public Health. 2000 May;8(2):77-9.

6. Morava E, Végh É, Bóna I, Kiss I, Oroszi B, Józan P. Health risk factors and mortality in Pécs City, Hungary in the 1990s. Cent Eur J Public Health. 2000 May;8(2):109-13.

7. Indulski JA, Lutz W. Ischaemic heart disease as an effect of obesity-related metabolic disturbances. Cent Eur J Public Health. 1999 Aug;7(3):122-9.

8. Milewicz A, Jedrzejuk D, Lwow F, Białynicka AS, Lopatynski J, Mardarowicz G, et al. Prevalence of obesity in Poland. Obes Rev. 2005 May;6(2):113-4.

9. Kozieł S, Welon Z, Bielicki T, Szklarska A, Ulijaszek S. The effect of the economic transition on the body mass index of conscripts in Poland. Econ Hum Biol. 2004 Mar;2(1):97-106.

10. Szponar L, Sekuła W, Rychlik E, Ołtarzewski M, Figurska K. Household food consumption and anthropometric survey. Prace IŻŻ. 2003;101:230443. (In Polish.)

11. Biela U, Pająk A, Kaczmarczyk-Chałas K, Głuszek J, Tendera M, Waśkiewicz A, et al. Incidence of overweight and obesity in women and men between the ages of 20-74. Results of the WOBASZ program. Kardiol Pol. 2005;63(6 Suppl 4):S632-5. (In Polish.)

12. Central Statistical Office. Health status of the Polish population in 2009 [Internet]. Warsaw: Central Statistical Office; 2011 [cited 2012 Jan 4]. Available from: http://www.stat.gov.pl/cps/rde/xbcr/gus/ZO_stan_ zdrowia_2009.pdf. (In Polish.)

13. Polakowska M, Piotrowski W. Incidence of diabetes in the Polish population: results of the Multicenter Polish Population Health Status Study - WOBASZ. Pol Arch Med Wewn. 2011 May;121(5):156-63.

14. Zatonski WA, Willett W. Changes in dietary fat and declining coronary heart disease in Poland: population based study. BMJ. 2005;331(7510):187-8.

15. Zatoński W, Mańczuk M., Sulkowska U, editors; the HEM project team. Closing the health gap in European Union [Internet]. Warsaw: Maria Skłodowska-Curie Memorial Cancer Center and Institute of Oncology; 2008 [cited 2014 Mar 4]. Available from: http://www.hem.waw.pl/index. php?idm=87,139\&cmd=1.

16. World Health Organization. The WHO Global Infobase [Internet]. Geneva: WHO; c2010 [updated 2011 Jan 20; cited 2011 Jun 4]. Available from: https://apps.who.int/infobase/.

17. McPherson K, Marsh T, Brown M. Tackling obesities: future choices - modelling future trends in obesity and the impact on health [Internet]. Department of Innovation Universities and Skills; 2007 [cited 2011 Oct 7]. Available from: http://veilleagri.hautetfort.com/ media/02/00/2025691480.pdf.

18. Wang YC, McPherson K, Marsh T, Gortmaker SL, Brown M. Health and economic burden of the projected obesity trends in the USA and the UK. Lancet. 2011 Aug 27;378(9793):815-25.

19. Oblacińska A, Jodkowska M, Palczewska I, Tabak I. Value and usefulness of modified screening test for detection of overweight and obesity in school-aged children and adolescents. Med Wieku Rozwoj. 2007 Jul-Sep;11(3 Pt 1):275-80. (In Polish.)

20. Woynarowska B, Małkowska-Szkutnik A, Mazur J, Kowalewska A, Komosińska K. School meals and policy on promoting healthy eating in schools in Poland. Med Wieku Rozwoj. 2011 Jul-Sep;15(3):232-9.

21. Halicka E. Implementation of CAP programs aimed at increasing the consumption of fruit, vegetable and milk products in Polish schools. Probl World Agric. 2011;11(3):36-43.

22. Szponar L, Ciok J, Dolna A, Oltarzewski M. Policy options for responding to the growing challenge from obesity (PorGrow) in Poland. Obes Rev. 2007 May;8 Suppl 2:91-8.

23. Jarosz M, editor. POL HEALTH - The National Programme for the Prevention of Overweight and Obesity and Chronic Non-Communicable Diseases through the Improvement of Nutrition and Physical Activity 2007-2016. Warsaw: National Food and Nutrition Institute; 2006.

24. Visscher TLS, Viet AL, Kroesbergen HT, Seidell JC. Underreporting of BMI in adults and its effect on obesity prevalence estimations in the period 1998 to 2001. Obesity (Silver Spring). 2006 Nov;14(11):2054-63.

25. Macdiarmid J, Blundell J. Assessing dietary intake: Who, what and why of under-reporting. Nutr Res Rev. 1998 Dec;11(2):231-53. 
26. Bac A, Woźniacka R, Matusik S, Golec J, Golec E. Prevalence of overweight and obesity in children aged 6-13 years-alarming increase in obesity in Cracow, Poland. Eur J Pediatr. 2012 Feb;171(2):245-51.

27. Kosti RI, Panagiotakos DB. The epidemic of obesity in children and adolescents in the world. Cent Eur J Public Health. 2006 Dec;14(4):151-9.

28. Milewicz A, Jedrzejuk D, Lwow F, Białynicka AS, Lopatynski J, Mardarowicz G, et al. Prevalence of obesity in Poland. Obes Rev. 2005 May;6(2):113-4.
29. Vignerová J, Lhotská L, Bláha P. Proposed standard definition for child overweight and obesity. Cent Eur J Public Health. 2001 Aug;9(3):145-6.

30. Kopczyński J, Wojtyniak B, Goryński P, Lewandowski Z. The future of chronic diseases. Cent Eur J Public Health. 2001 Feb;9(1):3-13.

Received February 15, 2013 Accepted in revised form January 20, 2014 